\title{
EFFECT OF FATTY ACIDS ON PLASMA MEMBRANE LIPID DYNAMICS AND CATION PERMEABILITY IN NEUROBLASTOMA CELLS
}

JOHANNES BOONSTRA, S. AD NELEMANS, ALIE FEIJEN, ARJO BIERMAN, EVERARDUS J.J. VAN ZOELEN, PAUL T. VAN DER SAAG and SIEGFRIED W. DE LAAT

Hubrecht Laboratory, International Embryological Institute, Uppsalalaan 8, 3584 CT Utrecht (The Netherlands)

(Received June 21st, 1982)

Key words: Fatty acid supplementation; Membrane lipid dynamics; Cation permeability; Membrane potential; Fluorescent probe; (Mouse neuroblastoma cell)

In this study the effects of experimental modifications of plasma membrane lipid lateral mobility on the electrical membrane properties and cation transport of mouse neuroblastoma cells, clone Neuro-2A, have been studied. Short-term supplementation of a chemically defined growth medium with oleic acid or linoleic acid resulted in an increase in the lateral mobility of lipids as inferred from fluorescence recovery after photobleaching of the lipid probe 3,3'-dioctadecylindocarbocyanide iodide. These changes were accompanied by a marked depolarization of the membrane potential from $-51 \mathrm{mV}$ to $-36 \mathrm{mV}, 1.5 \mathrm{~h}$ after addition, followed by a slow repolarization. Tracer flux studies, using ${ }^{86} \mathbf{R b}^{+}$as a radioactive tracer for $\mathbf{K}^{+}$, demonstrated that the depolarization was not caused by changes in $\left(\mathrm{Na}^{+}+\mathrm{K}^{+}\right)$-ATPase-mediated $\mathrm{K}^{+}$influx or in the transmembrane $\mathrm{K}^{+}$gradient. The permeability ratio $\left(\boldsymbol{P}_{\mathrm{Na}} / \boldsymbol{P}_{\mathrm{K}}\right)$, determined from electrophysiological measurements, however, increased from 0.10 to 0.27 upon supplementation with oleic acid or linoleic acid. This transient rise of $P_{\mathrm{Na}} / P_{\mathrm{K}}$ was shown by ${ }^{24} \mathrm{Na}^{+}$and ${ }^{86} \mathrm{Rb}^{+}$flux measurements to be due to both an increase of the $\mathrm{Na}^{+}$permeability and a decrease of the $\mathrm{K}^{+}$permeability. None of these effects occurred upon supplementation of the growth medium with stearic acid.

\section{Introduction}

In neuroblastoma cells, transition from mitosis to early $G_{1}$-phase is associated with a 2-fold decrease in the microviscosity of the membrane lipid bilayer [1], a comparable increase in the lateral mobility of lipids and proteins [2] and a decrease in the density and a rearrangement in the spatial distribution of intramembrane particles [3]. In addition, modulations of functional properties of the plasma membrane have been observed during transition from mitosis to $G_{1}$-phase, including a depolarization of the membrane potential and a

Abbreviation: Hepes, 4-(2-hydroxyethyl)-1-piperazineethanesulphonic acid. decrease in the intracellular $\mathrm{K}^{+}$activity [4]. These latter changes were found to be due to decreased $\mathrm{Na}^{+}$and $\mathrm{K}^{+}$permeability [4] and to decreased $\left(\mathrm{Na}^{+}+\mathrm{K}^{+}\right)$-ATPase activity $[5,6]$.

Increases in cell surface area during the cell cycle of neuroblastoma cells occur principally just before and during mitosis [4], while a high rate of phospholipid synthesis is known to occur during $\mathrm{G}_{1}$-phase in various other cell lines [7-11]. Furthermore, an excellent correlation has been demonstrated between lateral mobility of plasma membrane proteins and the optimal activity of the $\mathrm{Na}^{+}, \mathrm{K}^{+}$-pump during the cell cycle of neuroblastoma cells [6]. It is believed that the coordinated modulations of structural and functional plasma membrane properties during the cell cycle 
are a consequence of phase-specific insertion of new membrane components during the cell cycle [12-14].

In the present paper we have analyzed to what extent alterations in the degree of unsaturation of phospholipids could contribute to changes in cation transport properties.

The lipid composition of the plasma membrane can be modified experimentally through, for example, cholesterol depletion [15-20], or accumulation [21]; modification of the polar head-groups of the phospholipids [22-24], or modification of the fatty acid composition [25-30]. A change in phospholipid composition upon supplementation with stearic acid, oleic acid or linoleic acid has been described in neuroblastoma x glioma hybrid cells [29] and other cell lines [31,32].

We have studied the effects of supplementation of serum-free, chemically defined growth medium with fatty acids on neuroblastoma cells. Supplementation of the growth medium with the cis-unsaturated fatty acids oleic and linoleic acid, resulted in an increase in lateral mobility of lipids, a depolarization of membrane potential and an increase of the permeability ratio to $\mathrm{Na}^{+}$and $\mathrm{K}^{+}$. Tracer flux studies showed that these last two effects are due to a specific increase of the $\mathrm{Na}^{+}$ permeability and a decrease in $\mathrm{K}^{+}$permeability, with no effects on active $\mathrm{K}^{+}$transport via the $\left(\mathrm{Na}^{+}+\mathrm{K}^{+}\right)$-ATPase.

\section{Materials and Methods}

\section{Cell culture and fatty acid supplementation}

C1300 mouse neuroblastoma cells, clone Neuro-2A, were originally obtained from the American Type Culture Collection, Rockville, MD, U.S.A. The cells were grown routinely in Dulbecco's modified Eagle's medium buffered with $25 \mathrm{mM}$ Hepes at $\mathrm{pH} 7.5$ and supplemented with $10 \%$ fetal calf serum (Flow) at $37^{\circ} \mathrm{C}$ in a humidified atmosphere. The cell doubling time is approx. $8-9 \mathrm{~h}, 60-70 \%$ of the cells being in S-phase during exponential growth $[1,33]$.

For fatty acid supplementation, cells were grown for $24 \mathrm{~h}$ on a chemically defined serum-free growth medium, containing equal amounts $F 12$ and Dulbecco's modified Eagle's medium, supplemented with $1.48 \mathrm{~g} / 1$ bicarbonate, $15 \mathrm{mM}$ Hepes,
$0.5 \mathrm{mg} / 1$ insulin, $100 \mathrm{mg} / 1$ transferrin and 7.9 $\mathrm{mg} / 1$ sodium selenite at $37^{\circ} \mathrm{C}$ in a humidified $2 \%$ $\mathrm{CO}_{2}$ atmosphere [34]. The cell doubling time in this medium under the experimental conditions described below was $12-13 \mathrm{~h}$. For fatty acid incorporation and tracer flux experiments cells were plated at a density of $(0.5-1) \cdot 10^{5}$ cells $/ \mathrm{cm}^{2}$ in culture dishes $(3.5 \mathrm{~cm}$ diameter, Costar, Cambridge, MA, U.S.A.). For maximal $\left(\mathrm{Na}^{+}+\mathrm{K}^{+}\right)$ATPase activity measurements, cells were plated at similar densities on $150 \mathrm{~cm}^{2}$ tissue culture flasks (Costar). Cells were plated at similar densities for fluorescence photobleaching recovery measurements on glass culture coverslips and for electrophysiological measurements on plastic culture coverslips $\left(3.2 \mathrm{~cm}^{2}\right.$, Lux Scientific Corp., Thousand Oaks, CA, U.S.A.). All experiments were carried out at a final cell density of $(2-2.5) \cdot 10^{5}$ cells $/ \mathrm{cm}^{2}$.

Supplementation of the growth medium was as follows. Stearic acid, at a concentration of 10 $\mathrm{mg} / \mathrm{ml}$ in $50 \%$ ethanol, was diluted with $1 \%(\mathrm{w} / \mathrm{v})$ fatty acid-free bovine serum albumin in a $1: 1$ ratio, and this solution was added to growth medium containing $0.5 \%(\mathrm{w} / \mathrm{v})$ bovine serum albumin to a final fatty acid concentration of 40 $\mu \mathrm{g} / \mathrm{ml}$. Oleic acid and linoleic acid each at a concentration of $20 \mathrm{mg} / \mathrm{ml}$ in $100 \%$ ethanol were added directly to growth medium supplemented with $0.5 \%(\mathrm{w} / \mathrm{v})$ bovine serum albumin to a final fatty acid concentration of 40 and $20 \mu \mathrm{g} / \mathrm{ml}$, respectively. The ethanol concentration was $0.2 \%$ under all conditions. The control medium consisted of growth medium supplemented with $0.5 \%$ $(\mathrm{w} / \mathrm{v})$ bovine serum albumin and $0.2 \%$ ethanol.

\section{Fatty acid incorporation}

Total fatty acid incorporation into the cells was determined by adding $0.5 \mu \mathrm{Ci} / \mathrm{ml}\left[1-{ }^{14} \mathrm{C}\right]$ stearic acid, $\left[1-{ }^{14} \mathrm{C}\right]$ oleic acid or $\left[1-{ }^{14} \mathrm{C}\right]$ linoleic acid to the supplemented growth media, respectively. The incubation was terminated by removal of the growth medium and cells were subsequently washed five times with $1 \mathrm{ml}$ ice-cold phosphate-buffered saline. Cells were solubilized in $1 \mathrm{M} \mathrm{NaOH}$ and radioactivity assayed by liquid scintillation methods. Uptake was corrected for zero-time binding of labelled fatty acid to cells and/or dishes.

Incorporation of fatty acids into the various 
lipid fractions was determined from a $1.5 \mathrm{~h}$ incubation at $37^{\circ} \mathrm{C}$ as described above. The incubation was terminated by washing five times in Hepes-buffered saline comprising $20 \mathrm{mM}$ Hepes (pH 7.3)/130 mM NaCl/5.5 mM KCl/1.8 mM $\mathrm{CaCl}_{2} / 1 \mathrm{mM} \mathrm{MgCl}_{2}$. Cells were extracted using four times $1.5 \mathrm{ml}$ chloroform/methanol at $1: 2$ $(\mathrm{v} / \mathrm{v})$. Carrier lipids, i.e.: $90 \mathrm{nmol}$ phosphatidylcholine $\left(R_{\mathrm{F}}, 0\right), 10 \mathrm{nmol}$ phosphatidylserine $\left(R_{\mathrm{F}}, 0\right), 200 \mathrm{nmol}$ cholesterol $\left(R_{\mathrm{F}}, 0.15\right), 50 \mathrm{nmol}$ lanosterol $\left(R_{\mathrm{F}}, 0.21\right), 70 \mathrm{nmol}$ oleic acid $\left(R_{\mathrm{F}}\right.$, $0.28), 70 \mathrm{nmol}$ cholesterol oleate $\left(R_{\mathrm{F}}, 0.73\right)$ and $110 \mathrm{nmol}$ glycerol trioleate $\left(R_{\mathrm{F}}, 0.46\right)$, were added to the extract and the extracts were subsequently treated according to Bligh and Dyer [35]. $R_{\mathrm{F}}$ values of mono- and diacylglycerols were 0.05 and 0.12 , respectively.

Organic phases were dried under $\mathrm{N}_{2}$ at $40^{\circ} \mathrm{C}$ and samples were separated into different lipid classes by thin-layer chromatography on $20 \times 20$ $\mathrm{cm}$ glass plates coated with silica ${ }^{60} \mathrm{HR}$ and $2 \%$ florisil TLC with heptane/diethyl ether/acetic acid at $60: 15: 1(\mathrm{v} / \mathrm{v})$ as eluent. Lipid fractions were visualized by iodine vapour and after de-staining removed from the plates and counted for radioactivity.

\section{Fluorescence photobleaching recovery measurements}

The fluorescent lipid probe 3,3'-dioctadecylindocarbocyanide iodide was used to determine the lateral mobility of plasma membrane lipids. For labelling, cells were incubated at room temperature for $10 \mathrm{~min}$ in growth medium supplemented with $1 \%$ dioctadecylindocarbocyanide iodide solution $(2 \mathrm{mg} / \mathrm{ml}$ in ethanol). The labelling medium was removed and the cells washed three times with growth medium supplemented with $0.1 \%$ fatty acid free bovine serum albumin $(w / v)$ and three times with medium without bovine serum albumin. Lateral mobility was determined by fluorescence recovery after photobleaching essentially as described by Koppel et al. [36]. The fluorescent probe dioctadecylindocarbocyanide iodide was excitated with a $514 \mathrm{~nm}$ laser beam (Argon laser, Coherent CR-4) in the Gaussian mode focussed by a $50 \times$ water-immersion objective (N.A. $=1.00$ ) to a spot with an estimated radius of $1 \mu \mathrm{m}$. Bleaching was obtained by a short (10-30 ms) 1000-fold increase in light intensity, resulting in a 40-50\% reduction of fluorescence intensity.

Fluorescence intensity was measured by single photon counting using a photomultiplier tube (EMI 9863/100; EMI, Hayes, London, U.K.), an ORTEC 9301 fast preamplifier, and an ORTEX 9302 amplifier-discriminator (ORTEC Inc., Oak Ridge, TN, U.S.A.). An Apple II microcomputer controlled both the duration of the bleaching pulse and the intensity of the laser beam, and was also used for on-line analysis of the data. Half-times of recovery were used for determination of diffusion coefficients $(D)$ as described by Axelrod et al. [37].

\section{Fluorescence polarization measurements}

The fluorescent lipid probe, 1,6-diphenyl-1,3,5hexatriene was used to determine the fluidity properties of the plasma membrane lipid layer on intact cells [38]. Fluorescence labelling of the cells with diphenylhexatriene and fluorescence polarization measurements were performed as described in detail previously [1].

\section{Determination of membrane potential}

Membrane potentials ( $E_{\mathrm{m}}$ ) were measured using conventional $3 \mathrm{M} \mathrm{KCl}$-filled glass microelectrodes as described in detail previously [4].

Determination of relative membrane cation permeability

The permeability ratio $\left(P_{\mathrm{Na}} / P_{\mathrm{K}}\right)$ was obtained from membrane potential measurements under conditions of equimolar replacement of $\mathrm{Na}^{+}$by $\mathrm{K}^{+}$, and subsequently by plotting of $e^{E_{\mathrm{m}} F / R T}$ versus the extracellular $\mathrm{K}^{+}$activity $\left(a_{\mathrm{K}}^{\mathrm{o}}\right)$, as described in detail previously [39].

\section{$\mathrm{K}^{+}$and $\mathrm{Na}^{+}$flux measurements}

The $\left(\mathrm{Na}^{+}+\mathrm{K}^{+}\right)$-ATPase mediated $\mathrm{K}^{+}$influx was obtained on the difference between total and ouabain-insensitive $\mathrm{K}^{+}$influx, using a 5 min pulse with ${ }^{86} \mathrm{Rb}^{+}$as radioactive tracer, as described in detail previously [5]. $\mathrm{Na}^{+}$influx was determined from a 5 min pulse with ${ }^{24} \mathrm{Na}^{+}$as radioactive tracer in the presence of $5 \mathrm{mM}$ ouabain, as described elsewhere [40]. $\mathrm{K}^{+}$efflux was measured by the loss of ${ }^{42} \mathrm{~K}$ from the cells, prelabelled with the isotope for minimally $3 \mathrm{~h}$, as described in detail previously [39]. The $\mathrm{K}^{+}$permeability $\left(P_{\mathrm{K}}\right)$ was 
determined from $\mathrm{K}^{+}$efflux measurements with ${ }^{42} \mathrm{~K}^{+}$as a radioactive tracer and using the equations of conventional electrodiffusion theory as described before [39].

Determination of $\left(\mathrm{Na}^{+}+\mathrm{K}^{+}\right)$-ATPase activity

Cells were lysed in a buffer comprising $1 \mathrm{mM}$ $\mathrm{NaHCO}_{3} / 10 \mathrm{mM}$ Tris $/ 2 \mathrm{mM}$ dithiothreitol/0.5 mM EDTA ( $\mathrm{pH}$ 7.4). In homogenates obtained by Dounce homogenization, ouabain-sensitive ATP hydrolysis was measured according to the method described previously [5].

\section{Materials}

${ }^{42} \mathrm{KCl}$ (spec. act. $1 \mathrm{Ci} / \mathrm{mol}$ ) and ${ }^{24} \mathrm{NaCl}$ (spec. act. $1 \mathrm{Ci} / \mathrm{mol}$ ) were obtained from the Interuniversity Reactor Institute (Delft; The Netherlands). ${ }^{86} \mathrm{RbCl}$ (spec. act. $1 \mathrm{Ci} / \mathrm{mol}$ ) was obtained from the Amersham International (U.K). $\left[1-{ }^{14} \mathrm{C}\right]$ Stearic acid (spec. act. $51.5 \mathrm{mCi} / \mathrm{mmol}$ ), $\left[1-{ }^{14} \mathrm{C}\right]$ oleic acid (spec. act. $56.6 \mathrm{mCi} / \mathrm{mmol}$ and $\left[1-{ }^{14} \mathrm{C}\right]$ linoleic acid (spec. act. $56.5 \mathrm{mCi} / \mathrm{mmol}$ ) were obtained from New England Nuclear (Boston, MA, U.S.A.). Ouabain, stearic acid, oleic acid, linoleic acid, essentially fatty acid free bovine serum albumin, lanosterol, cholesterol oleate and glycerol trioleate were obtained from Sigma (St. Louis, MO, U.S.A.); diphenylhexatriene, phosphatidylcholine and cholesterol from Koch-Light Laboratories (Colnbrook, U.K.), and phosphatidylserine from Lipid Products (South Nutfield, U.K.). Dioctadecylindocarbocyanide iodide was kindly provided by $\mathrm{Dr}$.

A. Waggoner.

\section{Results}

Fatty acid incorporation and distribution into cellular lipid fractions

Supplementation of growth medium with stearic, oleic or linoleic acid resulted in uptake of all three fatty acids, as shown in Fig. 1. The uptake of stearic acid was, however, relatively low compared with that of oleic or linoleic acid and reached almost its maximal value after $1 \mathrm{~h}$ of supplementation. A $2 \mathrm{~h}$ incubation with oleic, linoleic or stearic acid resulted in a total incorporation of $10.0 \pm 0.2,7.0 \pm 0.7$ and $2.0 \pm 0.3 \mathrm{nmol} / 10^{6}$ cells (mean \pm S.E.) respectively. Subsequently, the distribution of the incorporated fatty acids over

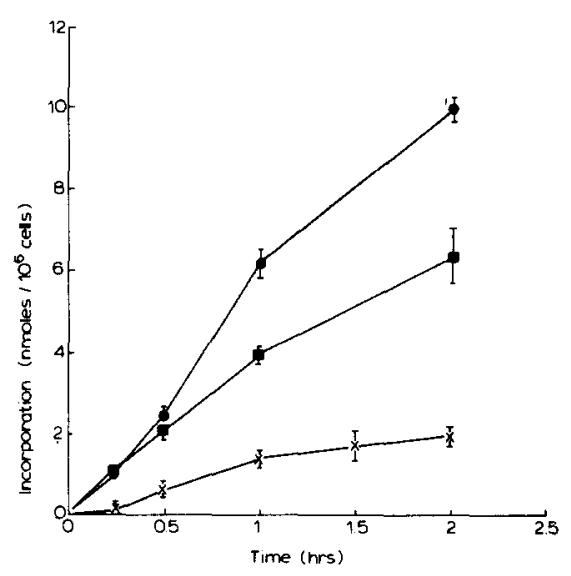

Fig. 1. Uptake of fatty acids into Neuro-2A cells. Total fatty acid uptake was measured using $\left[1-{ }^{14} \mathrm{C}\right]$ oleic acid $(\bullet-\bullet)$, $\left[1-{ }^{14} \mathrm{C}\right]$ linoleic acid $(\square-\square)$ or $\left[1-{ }^{14} \mathrm{C}\right]$ stearic acid $(X-\infty)$ as described under Methods. Data are presented as mean \pm S.E.

the various lipid fractions was determined after a $1.5 \mathrm{~h}$ incubation time, as shown in Table I. Oleic and linoleic acid were incorporated mainly into the phospholipid (approx. 45\%) and the triacylglycerol (approx. 40\%) fractions, while hardly any incorporation was found into the cholesterol or mono-+ diacylglycerol fractions. In contrast, stearic acid was present mainly as free fatty acid $(50 \%)$, and $30 \%$ was incorporated into the phospholipid and $10 \%$ into the triacylglycerol fractions. The amount of stearic acid incorporated into the

\section{TABLE I}

\section{FATTY ACID INCORPORATION IN NEURO-2A CELLS}

Growth medium was supplemented with $\left[1-{ }^{14} \mathrm{C}\right]$ stearic acid, $\left[1-{ }^{14} \mathrm{C}\right]$ oleic acid or $\left[1-{ }^{14} \mathrm{C}\right]$ linoleic acid for $1.5 \mathrm{~h}$ at $37^{\circ} \mathrm{C}$. Fatty acid incorporation into various lipid fractions was determined as described under Methods. Data present the mean value of duplicate determinations.

\begin{tabular}{lrrr}
\hline \multirow{2}{*}{ Lipid fraction } & \multicolumn{3}{l}{ Incorporation $\%$} \\
\cline { 2 - 4 } & $18: 0$ & $18: 1$ & $18: 2$ \\
\hline Phospholipid & 29.6 & 47.8 & 43.4 \\
Free cholesterol & 2.3 & 1.4 & 2.9 \\
Cholesteryl ester & 1.0 & 0.7 & 0.9 \\
Fatty acid & 50.2 & 0.9 & 0.7 \\
Mono+ diacylglycerol & 2.1 & 1.7 & 3.8 \\
Triacylglycerol & 9.1 & 44.1 & 42.6 \\
\hline
\end{tabular}


phospholipid fraction is about 10-fold less than the incorporation of oleic or linoleic acid into the phospholipid fraction.

\section{Effect of fatty acid supplementation on dynamic plasma membrane properties}

The effects of supplementation of growth medium with stearic, oleic or linoleic acid on dynamic plasma membrane properties were studied by fluorescence recovery measurements after photobleaching using the fluorescent lipid probe dioctadecylindocarbocyanide iodide. The diffusion coefficient increased by approx. $20 \%$ upon supplementation of growth medium for $1.5 \mathrm{~h}$ with oleic or linoleic acid, while no effect was observed with stearic acid as compared to control cells (Table II). The mobile fraction of the label was approx. 90\%. These results demonstrated an increase of the lateral mobility of the plasma membrane lipids upon addition of cis-unsaturated fatty acids to the growth medium. These results were confirmed by fluorescence polarization measurements of the fluorescent lipid probe diphenylhexatriene, also demonstrating a decrease of the microviscosity of the lipid layer of the cellular membranes in the presence of oleic or linoleic acid in the growth medium, while stearic acid had no effect on the microviscosity (data not shown). These measurements demonstrate specific effects of the unsaturated fatty acids on the plasma membrane properties, in contrast to the saturated fatty acid, which results are in agreement with those presented by others [41-43].

\section{TABLE II}

\section{EFFECT OF FATTY ACID SUPPLEMENTATION ON} LATERAL LIPID MOBILITY

The diffusion coefficient, $D$, of the lipid probe dioctadecylindocarbocyanide iodide was measured $1.5 \mathrm{~h}$ after changing the medium for control medium or media supplemented with stearic acid, oleic acid or linoleic acid. Data presented as mean \pm S.E. The number of observations is shown in parentheses.

\begin{tabular}{lll}
\hline Supplementation & $D\left(\times 10^{9}\right)\left(\mathrm{cm}^{2} / \mathrm{s}\right)$ & Significance level \\
\hline None & $4.92 \pm 0.27(16)$ & \\
Stearic acid & $4.85 \pm 0.25(14)$ & \\
Oleic acid & $6.02 \pm 0.22(16)$ & $P<0.001$ \\
Linoleic acid & $6.17 \pm 0.25(18)$ & $P<0.001$ \\
\hline
\end{tabular}

Effect fatty acid supplementation on membrane potential

Supplementation of the growth medium with oleic acid resulted in a rapid depolarization of $E_{\mathrm{m}}$ from $-52.8 \pm 1.5 \mathrm{mV}$ (mean \pm S.E.), $(n=27)$ to $-37.3 \pm 3.9 \mathrm{mV}(n=33) 1.5 \mathrm{~h}$ after addition, followed by a repolarization to the control value of $-50.0 \pm 1.6 \mathrm{mV}(n=25) 4.5 \mathrm{~h}$ after addition (Fig. 2). A depolarization of $E_{\mathrm{m}}$ was also observed upon supplementation of linoleic acid, a minimal value of $-38.9 \pm 2.7 \mathrm{mV}(n=34)$ being reached $1.5 \mathrm{~h}$ after addition, but in this case only a slight repolarization occurred afterwards (Fig. 2). No significant changes in $E_{\mathrm{m}}$ were observed upon addition of stearic acid to the growth medium (Fig. 2). As has been reported in detail previously [39] $E_{\mathrm{m}}$ can be described according to the modified Goldman-Hodgkin-Katz equation assuming that $\mathrm{Cl}^{-}$is in thermodynamic equilibrium with $E_{\mathrm{m}}$. Therefore, changes in $E_{\mathrm{m}}$ might be due to changes of the $\mathrm{K}^{+}$gradient (e.g., the ion-pump activity) and/or in the permeabilities of the membrane towards $\mathrm{K}^{+}$and $\mathrm{Na}^{+}$.

Effects of fatty acid supplementation on $\left(\mathrm{Na}^{+}+\right.$ $\mathrm{K}^{+}$)-ATPase activity and $\mathrm{K}^{+}$gradient

The $\mathrm{K}^{+}$gradient across the plasma membrane is mainly determined by the activity of the $\left(\mathrm{Na}^{+}\right.$ $+\mathrm{K}^{+}$)-ATPase and the $\mathrm{K}^{+}$permeability [39].

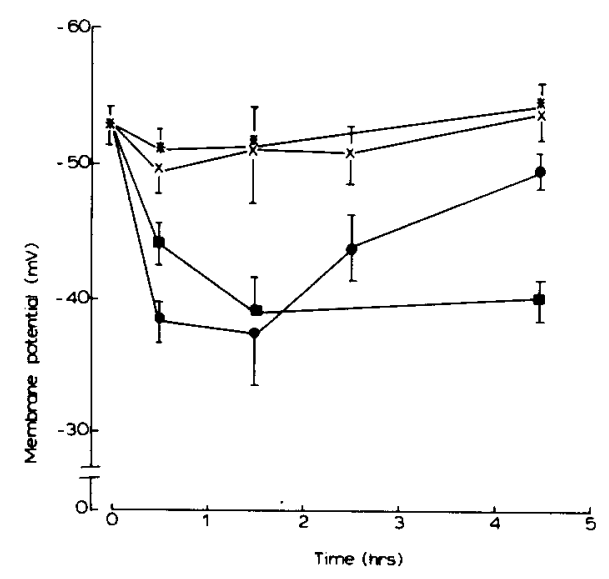

Fig. 2. Effect of fatty acid supplementation on membrane potential. Cells growing in control medium $(\star-\star)$ or in media supplemented with stearic acid $(x-\times)$, oleic acid $(\bullet)$ or linoleic acid (ロ_- Data given as mean \pm S.E. 
Using the cardiac glycoside ouabain as an inhibitor of the $\left(\mathrm{Na}^{+}+\mathrm{K}^{+}\right)$-ATPase, the $\left(\mathrm{Na}^{+}+\mathrm{K}^{+}\right)$ATPase-mediated $\mathrm{K}^{+}$influx has been obtained as the difference between total and ouabain-insensitive influx using a 5 min pulse $[5,39,44]$, with ${ }^{86} \mathrm{Rb}^{+}$as a radioactive tracer for $\mathrm{K}^{+}[39,44]$. The effects of supplementation of stearic acid, oleic acid, or linoleic acid on active $\mathrm{K}^{+}$transport were determined at various times up to $2 \mathrm{~h}$ after addition of the fatty acids. During this period, no significant difference was observed between $\mathrm{K}^{+}$ influx in the presence of these fatty acids and the influx in cells in control medium, as shown for the $1.5 \mathrm{~h}$ point in Table III. Furthermore, no significant effect of fatty acid supplementation on $\mathrm{K}^{+}$ dependent ouabain-sensitive ATP hydrolysis in cell homogenates was observed under optimal substrate conditions (Table III). In conclusion, addition of the fatty acids to the growth medium affected neither the functional ( $\mathrm{K}^{+}$transport) not the optimal (ATP hydrolysis) $\left(\mathrm{Na}^{+}+\mathrm{K}^{+}\right)$-ATPase activity. Over the same time period, no significant effect of fatty acid supplementation was found on the $\mathrm{K}^{+}$content of the cells, as shown for the $1.5 \mathrm{~h}$ point in Table III. These results strongly indicate that the observed changes in $E_{\mathrm{m}}$ upon addition of the unsaturated fatty acids to the growth medium are due solely to a change in the permeability characteristics of the plasma membrane towards $\mathrm{K}^{+}$and/or $\mathrm{Na}^{+}$.

Effect of fatty acid supplementation on $\mathrm{K}^{+}$and $\mathrm{Na}^{+}$permeability

The ratio of the membrane permeabilities for $\mathrm{Na}^{+}$and $\mathrm{K}^{+}\left(P_{\mathrm{Na}} / P_{\mathrm{K}}\right)$ can be determined from $E_{\mathrm{m}}$ measurements under conditions of equimolar replacement of external $\mathrm{Na}^{+}$by $\mathrm{K}^{+}$. Under these conditions, plotting $e^{E_{\mathrm{m}} F / R T}$ against the extracellular $\mathrm{K}^{+}$activity $\left(a_{\mathrm{K}}^{\mathrm{o}}\right)(F, R$ and $T$ have their usual meaning) results in a straight line from which the permeability ratio $\left(P_{\mathrm{Na}} / P_{\mathrm{K}}\right)$ and the intracellular $\mathrm{K}^{+}$activity $\left(a_{\mathrm{K}}^{\mathrm{i}}\right)$ can be calculated [39]. In addition, the linearity of this relationship demonstrates the validity of applying the modified GoldmanHodgkin-Katz equation to $E_{\mathrm{m}}$ measurements in Neuro-2A cells under the experimental conditions.

Membrane potentials were measured at various extracellular $\mathrm{K}^{+}$concentrations $0.5,1.5$ and $2.5 \mathrm{~h}$ after supplementation of the growth medium with stearic acid, oleic acid or linoleic acid and in control cells. The linear regression lines through the experimentally determined points in a plot of $e^{E_{\mathrm{m}} F / R T}$ vs. $a_{\mathrm{K}}^{\mathrm{o}}$, were significant for $P<0.01$ under all conditions tested, indicating the validity of these measurements. The $P_{\mathrm{Na}} / P_{\mathrm{K}}$ ratios were subsequently calculated from the best fit of a plot of

\section{TABLE III}

\section{EFFECT OF FATTY ACID SUPPLEMENTATION ON MEMBRANE TRANSPORT CHARACTERISTICS}

Data (mean \pm S.E.) are given from determinations of various parameters $1.5 \mathrm{~h}$ after addition of the fatty acids. For explanation, see text. n.d., not determined.

\begin{tabular}{|c|c|c|c|c|c|c|c|}
\hline \multirow{4}{*}{$\begin{array}{l}\text { Membrane potential }\left(E_{\mathrm{m}}\right)(\mathrm{mV}) \\
\text { Intracellular } \mathrm{K}^{+} \text {activity }\left(a_{\mathrm{K}}^{\mathrm{i}}\right)(\mathrm{mM}) \\
\text { Intracellular } \mathrm{K}^{+} \text {content } \\
\quad\left(\mathrm{nmol} / 10^{6} \text { cells) }\right.\end{array}$} & \multicolumn{2}{|l|}{ Control } & Stearic acid & \multicolumn{2}{|l|}{ Oleic acid } & \multicolumn{2}{|c|}{ Linoleic acid } \\
\hline & -51.3 & \pm 2.5 & $-51.1 \pm 4$ & -37.3 & \pm 3.9 & -38.9 & \pm 2.7 \\
\hline & 109 & \pm 2 & $98 \pm 3$ & 118 & \pm 12 & 108 & \pm 5 \\
\hline & 189 & \pm 4 & 195 & 205 & \pm 4 & 193 & \pm 5 \\
\hline $\begin{array}{l}\text { Ouabain-sensitive } \mathrm{K}^{+} \text {influx } \\
\left(\mathrm{nmol} / \mathrm{min} \text { per } 10^{6} \text { cells }\right)\end{array}$ & 3.73 & \pm 0.23 & $3.42 \pm 0.29$ & 3.68 & \pm 0.32 & 3.46 & \pm 0.42 \\
\hline $\begin{array}{l}\text { Maximal }\left(\mathrm{Na}^{+}+\mathrm{K}^{+}\right) \text {-ATPase activity } \\
(\mu \mathrm{mol} \text { ATP } / \mathrm{h} \text { per mg protein) }\end{array}$ & 1.00 & \pm 0.05 & $0.91 \pm 0.04$ & 0.96 & \pm 0.08 & 0.92 & \pm 0.08 \\
\hline $\begin{array}{l}\mathrm{K}^{+} \text {exit rate constant }(k)\left(\min ^{-1}\right) \\
\text { Unidirectional } \mathrm{K}^{+} \text {efflux }\left(J_{\text {eff }}\right)\end{array}$ & 0.0180 & \pm 0.0001 & n.d. & 0.0180 & \pm 0.001 & .0 .0181 & $1 \pm 0.0001$ \\
\hline$\left(\mathrm{pmol} / \mathrm{cm}^{2}\right.$ per $\left.\mathrm{s}\right)$ & 4.2 & \pm 0.5 & n.d. & 4.6 & \pm 0.7 & 4.3 & \pm 0.6 \\
\hline $\mathrm{K}^{+}$permeability $\left(P_{\mathrm{K}}\right)(\mathrm{cm} / \mathrm{s})\left(\times 10^{-8}\right)$ & 6.8 & \pm 0.6 & n.d. & 4.8 & \pm 0.4 & 5.2 & \pm 0.4 \\
\hline $\mathrm{Na}^{+}$permeability $\left(P_{\mathrm{Na}}\right)(\mathrm{cm} / \mathrm{s})\left(\times 10^{-9}\right)$ & 6.6 & \pm 0.6 & n.d. & 13.6 & \pm 1.1 & 14.3 & \pm 1.2 \\
\hline
\end{tabular}


$E_{\mathrm{m}}$ vs. $a_{\mathrm{K}}^{\mathrm{o}}$ and are shown in Fig. 3. No significant difference in $P_{\mathrm{Na}} / P_{\mathrm{K}}$ was observed upon supplementation of the growth medium with stearic acid, but a large increase was measured upon addition of oleic acid or linoleic acid, the maximal value obtained $1.5 \mathrm{~h}$ after the addition (Fig. 3). The intracellular $\mathrm{K}^{+}$activity calculated from these lines, however, did not change significantly upon supplementation with any of the fatty acids used (Table III), demonstrating again that no significant change occurred in the $\mathrm{K}^{+}$gradient, in agreement with the results presented above.

In Neuro-2A cells the $\mathrm{K}^{+}$permeability $\left(P_{\mathrm{K}}\right)$ can be determined readily from $\mathrm{K}^{+}$efflux measurements, since $\mathrm{K}^{+}$efflux from these cells is composed mainly of an electrodiffusional flux [39]. Using ${ }^{42} \mathrm{~K}^{+}$as a radioactive tracer, no changes were observed in $\mathrm{K}^{+}$exit rate constant upon supplementation of the growth medium with oleic acid or linoleic acid as compared to control cells (Table III), values being $0.0180 \pm 0.0001 \mathrm{~min}^{-1}$. Using the the value of cell surface area [39], and calculating the intracellular $\mathrm{H}_{2} \mathrm{O}$ volume as described previously [39], $\mathrm{K}^{+}$efflux was calculated to be $4.2 \pm 0.5,4.6 \pm 0.6$ and $4.3 \pm 0.5 \mathrm{pmol}$ $\mathrm{K}^{+} / \mathrm{cm}^{2}$ per $\mathrm{s}$ in control, oleic-acid-supplemented and linoleic-acid-supplemented cells, respectively (Table III).

The $\mathrm{K}^{+}$permeability $\left(P_{\mathrm{K}}\right)$ depends upon $\mathrm{K}^{+}$

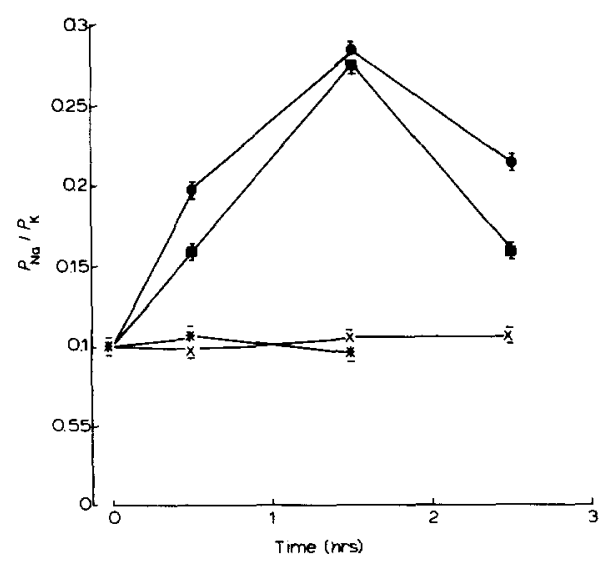

Fig. 3. Effect of fatty acid supplementation on the plasma membrane permeability ratio $P_{\mathrm{Na}} / P_{\mathrm{K}}$. Cells growing in control medium $(\star-\star$ ) or in media supplemented with stearic acid $(\times-\times)$, oleic acid $(-\bullet)$ or linoleic acid (a). Data given as mean \pm S.E. efflux and $E_{\mathrm{m}}$, and can be calculated using the equation of conventional electrodiffusion theory as has been described in detail previously [39]. As shown in Table III, $P_{\mathrm{K}}$ decreased slightly $1.5 \mathrm{~h}$ after supplementation with oleic acid or linoleic acid compared with control cells. In contrast, however, $P_{\mathrm{Na}}$ increased upon supplementation from $(6.6 \pm 0.6) \cdot 10^{-9} \mathrm{~cm} / \mathrm{s}$ in control cells to $(13.6 \pm$ $1.1) \cdot 10^{-9} \mathrm{~cm} / \mathrm{s}$ and $(14.3 \pm 1.2) \cdot 10^{-9} \mathrm{~cm} / \mathrm{s}$ in the presence of oleic acid and linoleic acid, respectively '(Table III).

Direct experimental evidence for an increase in $P_{\mathrm{Na}}$ from ${ }^{24} \mathrm{Na}^{+}$influx measurements is presented in Table IV. A significant $(P<0.001)$ increase is observed in total unidirectional $\mathrm{Na}^{+}$influx both 1 and $2 \mathrm{~h}$ after supplementation of the growth medium with oleic acid or linoleic acid as compared with control cells. Analogously to the calculation of $P_{\mathrm{K}}, P_{\mathrm{Na}}$ can be obtained using the equation of conventional electrodiffusion theory, as has been described for $P_{\mathrm{K}}$ in detail previously [39]. Using the $\mathrm{Na}^{+}$influx data from Table IV, fatty acid supplementation results in an increase in $P_{\mathrm{Na}}$ of the same order of magnitude as that calculated from electrophysiological and $\mathrm{K}^{+}$flux data, shown in Table III.

The conclusion from the results, presented above, is that short-time supplementation of the growth medium of Neuro-2A cells with cis-unsaturated fatty acids results in specific changes of the cation permeability properties of the plasma membrane.

\section{TABLE IV}

EFFECT OF FATTY ACID SUPPLEMENTATION ON TOTAL UNIDIRECTIONAL $\mathrm{Na}^{+}$INFLUX

Growth medium was supplemented with oleic or linoleic acid and $\mathrm{Na}^{+}$influx measured as described under Methods. Data given as mean \pm S.E.

\begin{tabular}{llrl}
\hline Time (h) & \multicolumn{3}{l}{$\mathrm{Na}^{+}$influx $\left(\mathrm{nmol} / \mathrm{min}\right.$ per $10^{6}$ cells $)$} \\
\cline { 2 - 4 } & Control & Oleic acid & Linoleic acid \\
\hline 1 & $7.31 \pm 0.65$ & $9.80 \pm 0.91$ & $10.54 \pm 1.27$ \\
2 & $7.18 \pm 0.30$ & $10.87 \pm 0.98$ & $10.78 \pm 0.83$ \\
\hline
\end{tabular}




\section{Discussion}

The temporal similarities in structural, dynamic and functional plasma membrane properties during the cell cycle of neuroblastoma cells [1-6] suggest a causal relationship between these properties. This relationship may possibly be based on variations in the plasma membrane composition during the cell cycle, due to cell cycle phase specific insertion of membrane components [14].

Experimentally, one way in which the plasma membrane lipid composition can be modulated is by supplementation of the growth medium fatty acids [25,29-31]. Addition of oleic or linoleic acid for about $4 \mathrm{~h}$ to the growth medium of neuroblastoma cells (clone Neuro-2A) had dramatic effects on functional plasma membrane properties, such as a depolarization of membrane potential (Fig. 2) and an increase in the membrane permeability ratio towards $\mathrm{Na}^{+}$and $\mathrm{K}^{+}$(Fig. 3). Analysis of the underlying mechanism of these changes revealed that the supplementation caused specifically an increase in $\mathrm{Na}^{+}$and a small decrease in $\mathrm{K}^{+}$permeability (Tables III and IV). The $\mathrm{K}^{+}$ gradient and $\left(\mathrm{Na}^{+}-\mathrm{K}^{+}\right)$-ATPase activity (Table III) remained unaffected.

This supplementation of the growth medium with oleic or linoleic acid also resulted in an increase of the lateral mobility of lipids in the plasma membrane. In these experiments the contribution of intracellularly located fluorescent lipid probe was excluded, since complete fluorescent recovery occurred following the kinetics for a single diffusion coefficient.

These experiments therefore clearly demonstrate a specific effect of $c i s$-unsaturated fatty acids on dynamic plasma membrane properties. In contrast, no change occurred in functional and dynamic plasma membrane properties upon supplementation of growth medium with stearic acid, supporting the view of a causal relationship between dynamic and functional plasma membrane properties.

The incorporation of stearic acid into the total phospholipid fraction is considerably lower than the incorporation of oleic or linoleic acid, as inferred from Fig. 1 and Table I. Based upon a total phospholipid content of approx. $100 \mathrm{nmol} / 10^{6}$ cells (Nelemans, unpublished data), the incorpora- tion can be calculated as approx. 2, 12 and 8\% with stearic, oleic and linoleic acid, respectively. This difference alone, however, does not explain the lack of effects of stearic acid, since the amount incorporated into the phospholipid fraction after a $2 \mathrm{~h}$ supplementation period is of the same order of magnitude as the amount of unsaturated fatty acid incorporated after a $30 \mathrm{~min}$ supplementation period, while in this latter case considerable effects already were observed (Figs. 2 and 3). The reason for the difference in uptake between stearic acid on the one hand and the unsaturated fatty acids on the other are not known, but any involvement of the fatty acid/albumin ratio on the uptake can be excluded because this ratio was in a range over which the binding of fatty acids to bovine serum albumin was not different [45]. The possible involvement of a cytoplasmic fatty acid binding protein in incorporation might, however, explain the observed differences. The affinity of this protein for fatty acids is in the order stearic $\ll$ linoleic $<$ oleic acid [46]. As shown in Table I, the unsaturated fatty acids are incorporated mainly into the phospholipid and triacylglycerol fractions, while hardly any free fatty acid was detected in the cells. These findings exlcude direct effects of the fatty acids upon the parameters measured. Furthermore, triacylglycerols are not considered as membrane constituents, although recent reports indicate the presence of triacylglycerols in the plasma membrane phospholipid bilayer [47]. It seems reasonable to conclude that the effects of oleic and linoleic acid on plasma membrane properties are due to incorporation, via deacylation-reacylation reactions, into the plasma membrane phospholipid fraction.

The results suggest that modulations in dynamic and permeability plasma membrane properties during the cell cycle of Neuro-2A cells could arise in part from modulations in the degree of phospholipid unsaturation. Experiments are being undertaken to determine the lipid composition of purified plasma membranes derived from synchronized cultures which might provide a biochemical basis for this view.

\section{Acknowledgements}

We thank Dr. W.H. Moolenaar and Dr. C.L. Mummery for valuable suggestions, and Ms. W.M. 
Miltenburg-Vonk and Mr. P. Meyer for skillful technical assistance. This work was supported in part by the Koningin Wilhelmina Fonds (Netherlands Cancer Foundation) and the Foundation for Fundamental Biologial Research (BION), which is subsidised by the Netherlands Organization for the Advancement of Pure Research (ZWO).

\section{References}

1 De Laat, S.W., Van der Saag, P.T. and Shinitzky, M. (1977) Proc. Natl. Acad. Sci. U.S.A. 75, 4458-4461

2 De Laat, S.W., Van der Saag, P.T., Elson, E.L. and Schlessinger, J. (1980) Proc. Natl. Acad. Sci. U.S.A. 77, 1526-1528

3 De Laat, S.W., Tertoolen, L.G.J., Van der Saag, P.T. and Bluemink, J.G. (1982) J. Cell Biol., submitted

4 Boonstra, J., Mummery, C.L., Tertoolen, L.G.J., Van der Saag, P.T. and De Laat, S.W. (1981) J. Cell. Physiol. 107, 75-83

5 Mummery, C.L., Boonstra, J., Van der Saag, P.T. and De Laat, S.W. (1981) J. Cell. Physiol. 107, 1-9

6 Van Zoelen, E.J.J., Mummary, C.L., Boonstra, J., Van der Saag, P.T. and De Laat, S.W. (1982) J. Cell. Biochem., submitted

7 Dubois, C. and Rampini, C. (1978) Biochimie 60, 1307-1313

8 Dirringer, H. and Friis, R.R. (1977) Cancer Res. 37. 2979-2984

9 Dubois, C. and Rampini, C. (1979) Biochem. Biophys. Res. Commun. 87, 253-257

10 Hoffmann, R., Erzberger, P., Frank, W. and Ristow, H.J. (1980) Biochim. Biophys. Acta 618, 282-292

11 Ristow, H.J., Messmer, T.O., Walter, S. and Paul, D. (1980) J. Cell. Physiol. 103, 263-269

12 De Laat, S.W. and Van der Saag, P.T. (1981) Int. Rev. Cytol. 74, 1-54

13 Porter, K., Prescott, D. and Frye, J. (1973) J. Cell Biol. 57, 815-836

14 Bluemink, J.G. and De Laat, S.W. (1977) in The Synthesis, Assembly and Turnover of Cell Surface Components (Poste, G. and Nicolson, G.L. eds.), pp. 403-461, Elsevier/NorthHolland Biomedical Press, Amsterdam

15 Chen, H.W., Heiniger, H.J. and Kandutsch, A.A. (1977) Exp. Cell Res. 109, 253-262

16 Kandutsch, A.A. and Chen, H.W. (1977) J. Biol. Chem. 252, 409-415

17 Chen, H.W., Heiniger, H.J. and Kandutsch, A.A. (1978) J. Biol. Chem. 253, 3180-3185

18 Le Grimmellec, C. and LeBlanc, G. (1978) Biochim. Biophys. Acta 514, 152-163

19 Le Grimmellec, C. and LeBlanc, G. (1980) Biochim. Biophys. Acta 599, 639-651

20 Bakker-Grunwald, T. and Sinensky, M. (1979) Biochim. Biophys. Acta 558, 296-306

21 Heron, D.S., Shinitzky, M., Hershkowitz, M. and Samuel,
D. (1980) Proc. Natl. Acad. Sci. U.S.A. 77, 7463-7467

22 Malkiewicz-Wasowicz, B., Gamst, O. and Stromme, J.H. (1977) Biochim. Biophys. Acta 482, 358-369

23 Engelhard, V.H., Glaser, M. and Storm, D.R. (1978) Biochemistry $17,3191-3200$

24 Gidwitz, S., Pessin, J.E., Weber, M.J., Glaser, M. and Storm, D.R. (1980) Biochim. Biophys. Acta 628, 263-276

25 Spector, A.A., Kiser, R.E., Denning, G.M., Koh, S.-W.M. and De Bault, L.E. (1979) J. Lipid Res. 20, 536-547

26 Doi, O., Doi, F., Schroeder, F., Alberts, A.W. and Vagelos, P.R. (1978) Biochim. Biophys. Acta 509, 239-250

27 Hoover, R.L., Lynch, R.D. and Karnovsky, M.J. (1977) Cell $12,295-300$

28 Ryan, J. and Simoni, R.D. (1980) Biochim. Biophys. Acta $598,606-615$

29 McGee, R. (1981) Biochim. Biophys. Acta 663, 314-328

30 Poon, R., Richards, J.M. and Clark, W.R. (1981) Biochim. Biophys. Acta 649, 58-66

31 Stubbs, C.D., Tsang, W.M., Belin, J., Smith, A.D. and Johnson, S.M. (1980) Biochemistry 19, 2756-2762

32 Gilmore, R., Cohn, N. and Glaser, M. (1979) Biochemistry 18, 1042-1049

33 Van Zoelen, E.J.J., Van der Saag, P.T. and De Laat, S.W. (1981) Exp. Cell Res. 131, 395-406

34 Bottenstein, J.E. and Sato, G.H. (1979) Proc. Natl. Acad. Sci. U.S.A. 76, 514-517

35 Bligh, E.G. and Dyer, W.J. (1959) Can. J. Biochem. Phys. 37, 911-917

36 Koppel, D.E., Axelrod, D., Schlessinger, J., Elson, E.L. and Webb, W.W. (1976) Biophys. J. 16, 1315-1329

37 Axelrod, D., Koppel, D.E., Schlessinger, J., Elson, E.L. and Webb, W.W. (1976) Biophys. J. 16, 1055-1069

38 Shinitzky, M. and Barenholz, Y. (1974) J. Biol, Chem. 249, 2652-2657

39 Boonstra, J., Mummery, C.L., Tertoolen, L.G.J., Van der Saag, P.T. and De Laat, S.W. (1981) Biochim. Biophys. Acta $643,89-100$

40 Mummery, C.L., Boonstra, J., Van der Saag, P.T. and De Laat, S.W. (1982) J. Cell. Physiol. 112, 27-34

41 McVey, E., Yguerabide, J., Hanson, D.C. and Clark, W.R. (1981) Biochim. Biophys. Acta 642, 106-118

42 Yamane, I. and Tomioka, F. (1979) Cell Biol. Int. Rep. 3, 515-523

43 Klausner, R.D., Kleinfeld, A.M., Hoover, R.L. and Karnovsky, M.J. (1980) J. Biol. Chem. 255, 1286-1295

44 Van Zoelen, E.J.J., Tertoolen, L.G.J., Boonstra, J., Van der Saag, P.T. and De Laat, S.W. (1982) Biochim. Biophys. Acta 720, 223-234

45 Spector, A.A., John, K. and Fletcher, J.E. (1969) J. Lipid Res. 10, 56-67

46 Ockner, R.K., Manning, J.A., Poppenhausen, R.B. and Ho, W.K.L. (1972) Science 177, 56-58

47 Johnson, S.M. (1981) in Fluorescent Probes (Beddard, G.S. and West, M.A., eds.), pp. 143-159, Academic Press, New York 